\title{
Why do Hong Kong patients need total hip arthroplasty? An analysis of 512 hips from 1998 to 2010
}

\author{
Vincent WK Chan *, PK Chan, KY Chiu, CH Yan, FY Ng
}

\section{A B S T R A C T}

Introduction: The number of patients undergoing total hip replacement surgeries has increased as a result of a rise in the ageing population. This study reviewed the demographics and disease spectrum leading to primary total hip replacement in the Chinese population from 1998 to 2010.

Methods: This case series was conducted in a university teaching hospital in Hong Kong. Data from the prospective joint registry of all patients who underwent primary total hip replacement from January 1998 to December 2010 were reviewed. Patients' age and sex, diagnosis, as well as the Harris Hip Scores before operation and at the last follow-up were described.

Results: There were 512 primary total hip replacements performed on 419 patients $(43.4 \%$ males) during the study period. All had clinical follow-up for at least 2 years. The mean age of the patients was 57.6 (standard deviation, 16.6) years. In males, the main aetiology was osteonecrosis (50.9\%), ankylosing spondylitis (19.5\%), and post-traumatic arthritis (8.5\%). For females, it was osteonecrosis

This article was published on 29 Sep 2015 at www.hkmj.org. (33.0\%), primary osteoarthritis (18.8\%), and posttraumatic arthritis (15.8\%). Alcohol-induced (52.5\%)

and idiopathic $(40.7 \%)$ was the most common cause of osteonecrosis in males and females, respectively. The mean preoperative Harris Hip Score and that at last follow-up was 43.9 (standard deviation, 18.3) and 89.7 (standard deviation, 13.0), respectively.

Conclusions: Osteonecrosis was the most common aetiology leading to total hip replacement although there were different causes in both sexes leading to it. The clinical result in terms of Harris Hip Score was good for all patients who required total hip replacement.

\section{Hong Kong Med J 2016;22:11-5 DOI: $10.12809 / \mathrm{hkmj} 144483$}

VWK Chan *, MB, BS

PK Chan, FHKCOS, FHKAM (Orthopaedic Surgery)

KY Chiu, FHKCOS, FHKAM (Orthopaedic Surgery)

CH Yan, FHKCOS, FHKAM (Orthopaedic Surgery)

FY Ng, FHKCOS, FHKAM (Orthopaedic Surgery)

Department of Orthopaedics and Traumatology, Queen Mary Hospital, The University of Hong Kong, Pokfulam, Hong Kong

* Corresponding author: loveholika@gmail.com

New knowledge added by this stud

- This study updates the disease pattern and epidemiology underlying the need for primary total hip replacement (THR) in our local Hong Kong population. In addition, the different causes leading to osteonecrosis of the hip were analysed.

Implications for clinical practice or policy

- The results of this study could have major implications on public health. They reveal that alcohol and its related health hazards remain a major health concern in Hong Kong. Study of the epidemiology of primary THR may enable us to better allocate our health care resources.

\section{Introduction}

Arthritis is a common clinical condition and its prevalence is increasing worldwide. ${ }^{1-4}$ More than $20 \%$ of the United States population suffer from arthritis, and it is estimated that one in four may develop symptomatic hip osteoarthritis in their lifetime ${ }^{1,5}$ It is an important clinical problem and a major burden on the health care system. Total hip replacement (THR) significantly improves quality of life and functional disability. ${ }^{6-8}$ The number of THR surgeries has been increasing all around the world over the past 10 years. ${ }^{9-12}$

Osteoarthritis is the most common indication for THR in Caucasian populations. According to the Annual Report 2013 of the National Joint Registry for England, Wales and Northern Ireland, osteoarthritis was the most common cause of primary THR across all age-groups, accounting for more than $90 \%$ of those aged 50 years and above. ${ }^{10}$ Overall, 79.2\% of primary THRs from 1992 to 2011 in the Swedish population were due to primary osteoarthritis, with a decreasing trend observed in THR for inflammatory arthritis. ${ }^{11}$ As the prevalence of hip osteoarthritis is lower in Asians, ${ }^{13}$ the disease pattern for THR would also be expected to differ. A review of primary total hip arthroplasty (THA) 


\section{為何香港患者須接受顝關節置換手術? 從 1998 年至2010年的512宗病例分析 \\ 陳偉鈞、陳秉強、曲廣運、忻振凱、吳富源}

引言：隨着人口老化, 每年置換髖關節的人數也越來越多。本研究分 析由 1998 年至 2010 年期間首次接受髖關節置換手術病人的數據和疾病 模式。

方法: 本病例系列分析香港一所大學教學醫院內的資料, 搜集1998年 1 月至 2010 年 12 月期間首次接受哯關節置換手術病人的數據, 包括其 年齡、性別、診斷結果、手術前和最後一次隨訪評估的Harris髖關節 評分量表。

結果 : 研究期間共有 419 位患者首次接受了 512 次髖關節置換手術, 當 中男性佔 $43.4 \%$ 。這些患者最少有兩年隨訪期。他們平均57.6歲（標準 差16.6歲）。至於接受相關手術的主要原因, 男性患者主要為缺血性 壞死（ $50.9 \%)$ 、強直性關節炎 $(19.5 \%)$ 和創傷後關節炎 $(8.5 \%)$; 女性患者主要為缺血性壞死 $(33.0 \%)$ 、原發性骨關節炎 $(18.8 \%)$ 和 創傷後關節炎 $(15.8 \%)$ 。酒精引發的缺血性壞死是在男性患者中最 常見的成因 $(52.5 \%)$; 而突發性缺血性壞死則是女性患者中最常見 的成因 $(40.7 \%)$ 。手術前和最後一次隨訪評估的Harris髖關節評分量 表之平均得分分別為43.9（標準差18.3）和89.7（標準差13.0）。

結論：雖然導致男性和女性患者缺血性壞死的成因各有不同, 但缺血 性壞死仍是導致全顝關節置換手術的最常見原因。此外, Harris髖關 節評分量表中的得分反映曾接受過全髀關節置換手術患者的臨床結果 良好。
Hip Scores ${ }^{16}$ at follow-up were analysed. All patients had clinical follow-up for at least 2 years. The causes of THR were then compared with the data from 1972 to $1997 .{ }^{14}$ Chi squared test and Student's $t$ test were used for statistical analysis.

\section{Results}

A total of 512 THR surgeries were performed on 419 Chinese patients at QMH from January 1998 to December 2010. Of the cases, $43.4 \%$ were males and $48.4 \%$ were left hips. The mean ( \pm standard deviation) age at the time of operation was $57.6 \pm$ 16.6 years. The mean Harris Hip Score at the last follow-up increased significantly compared with that preoperatively $(89.7 \pm 13.0$ vs $43.9 \pm 18.3$; paired $t$ test, $\mathrm{P}<0.05)$ [Table 1].

Osteonecrosis was the most common cause of primary THR in both males and females in our study population, accounting for $50.9 \%$ and $33.0 \%$, respectively. The second most common cause was ankylosing spondylitis in males (19.5\%) and osteoarthritis in females (18.8\%). Post-traumatic arthritis was the third most common cause in both males (8.5\%) and females (15.8\%). Rheumatoid arthritis accounted for $2.5 \%$ of primary THRs in males and $9.4 \%$ in females. Dysplasia contributed to $4.1 \%$ and $8.0 \%$ of primary THRs in males and females, respectively (Table 2).

The underlying causes of osteonecrosis in females and males were further analysed. The cause of osteonecrosis was entered by the operating surgeon based on medical records, as well as clinical, radiological, and intra-operative findings. The most common cause of osteonecrosis was alcoholism in males (52.5\%) and idiopathic osteonecrosis in to 1997 showed that osteonecrosis was the most common cause, accounting for $45.6 \%$ of cases, while primary osteoarthritis contributed to $10.2 \%$ only. ${ }^{14}$ Singh et $\mathrm{al}^{15}$ found that in Singapore, $42 \%$ of THRs from 2004 to 2006 were due to osteonecrosis. There are no other recent updates, however.

In view of our ageing population and rising number of primary THRs, study of the epidemiology in our locality is important to further plan and budget our health care resources. This study reviewed the demographics and disease spectrum leading to primary THR in the Chinese population from 1998 to 2010 , and attempted to identify any changes since 1997.

\section{Methods}

All patients who underwent primary THR at Queen Mary Hospital (QMH), a university teaching hospital in Hong Kong, from January 1998 to December 2010 were reviewed. Diagnosis was made according to clinical, radiological, and intra-operative findings and entered by the surgeon. Non-Chinese patients were excluded from further analysis. Patients' age and sex, diagnosis, preoperative and latest Harris
TABLE I. Demographics of primary total hip replacement in Chinese patients at Queen Mary Hospital from 1998 to 2010

\begin{tabular}{lc}
\hline Demographics & Data* $^{*}$ \\
\hline Total No. of patients & 419 \\
Total No. of hips & 512 \\
Sex & $43.4 \%$ \\
$\quad$ Male & $56.6 \%$ \\
$\quad$ Female & $48.4 \%$ \\
Laterality & $51.6 \%$ \\
$\quad$ Left & \\
$\quad$ Right & $57.6 \pm 16.6(22-96)$ \\
Age (years) & \\
Harris Hip Score & $43.9 \pm 18.3(9-97)$ \\
Preoperative & $\pm 13.0(49-100)$ \\
\hline At last follow-up &
\end{tabular}

* Data are shown as No., \%, or mean \pm standard deviation (range) 
females (40.7\%). Steroid-induced and idiopathic osteonecrosis was the second and third most common causes in males, accounting for $26.7 \%$ and $15.0 \%$, respectively. In females, steroid-induced and post-traumatic osteonecrosis was the second and third most common causes, accounting for $29.7 \%$ and $23.1 \%$, respectively (Table 3 ).

Our data were compared with the results from a previous study from 1972 to 1997 of primary THR in the Chinese patients. ${ }^{14}$ We concluded that osteonecrosis remains the most common cause of primary THR in the Chinese population. Other

TABLE 2. Diseases leading to primary total hip replacement in the Chinese patients at Queen Mary Hospital from 1998 to 2010

\begin{tabular}{lrrr}
\hline & Total & Male & Female \\
\hline Osteonecrosis & $41.2 \%$ & $50.9 \%$ & $33.0 \%$ \\
Osteoarthritis & $12.5 \%$ & $5.1 \%$ & $18.8 \%$ \\
\hline Post-traumatic & $12.5 \%$ & $8.5 \%$ & $15.8 \%$ \\
\hline Ankylosing spondylitis & $10.4 \%$ & $19.5 \%$ & $2.5 \%$ \\
Rheumatoid arthritis & $6.3 \%$ & $2.5 \%$ & $9.4 \%$ \\
Dysplasia & $6.3 \%$ & $4.1 \%$ & $8.0 \%$ \\
Past tuberculosis infection & $1.8 \%$ & $0.9 \%$ & $2.5 \%$ \\
Others & $9.2 \%$ & $8.5 \%$ & $9.9 \%$ \\
\hline
\end{tabular}

TABLE 3. Causes of osteonecrosis in the Chinese patients receiving total hip replacement at Queen Mary Hospital from 1998 to 2010

\begin{tabular}{lcc}
\hline & Male & Female \\
\hline Alcohol-induced & $52.5 \%$ & $4.4 \%$ \\
Steroid-induced & $26.7 \%$ & $29.7 \%$ \\
Idiopathic & $15.0 \%$ & $40.7 \%$ \\
Post-traumatic & $5.0 \%$ & $23.1 \%$ \\
Post-radiation therapy & $0.8 \%$ & 0 \\
Diving & 0 & $2.2 \%$ \\
\hline
\end{tabular}

TABLE 4. Comparison of causes of primary total hip arthroplasty in the Chinese patients between $1972-1997^{14}$ and 1998-2010

\begin{tabular}{lccl}
\hline & $\begin{array}{c}\mathbf{1 9 7 2 -} \\
\mathbf{1 9 9 7 ^ { 1 4 }}\end{array}$ & $\begin{array}{c}\mathbf{1 9 9 8 - 2 0 1 0} \\
\text { (the present } \\
\text { study) }\end{array}$ & P value* \\
\hline Osteonecrosis & $45.6 \%$ & $41.2 \%$ & 0.15 \\
\hline Post-traumatic & $15.6 \%$ & $12.5 \%$ & 0.16 \\
\hline Ankylosing spondylitis & $13.3 \%$ & $10.4 \%$ & 0.15 \\
\hline Osteoarthritis & $10.2 \%$ & $12.5 \%$ & 0.26 \\
\hline Rheumatoid arthritis & $3.3 \%$ & $6.3 \%$ & 0.025 \\
\hline * Values were compared & & &
\end{tabular}


in Caucasians. According to their Annual Report 2011, the number of primary THRs steadily increased from 14312 in 2007 to 15945 in $2011 .{ }^{11}$ Primary osteoarthritis of the hip has been the most common cause of THA in Sweden for more than 20 years, accounting for $83 \%$ in 2011 , while idiopathic osteonecrosis only contributed to $3.2 \%$ in $2011 .{ }^{11}$ On the contrary, our study showed that osteonecrosis is the most common cause of THR in the Chinese population and osteoarthritis accounts for only $12.5 \%$. Such discrepancy is also observed in other studies in Asian populations. A recent publication in India found that osteonecrosis was the most common indication for THR, accounting for $49 \%$ of those performed from 2006 to 2012. ${ }^{21}$ In Singapore, $42 \%$ of THRs were due to osteonecrosis from 2004 to $2006 .{ }^{15}$ Although the exact underlying mechanism is unclear, the prevalence of hip osteoarthritis has been shown to be lower in Orientals than Caucasians. ${ }^{13}$

The proportion of primary THR performed in Sweden for inflammatory arthritis decreased over a period of 5 years, from $2.08 \%$ in 2007 to $1.51 \%$ in $2011 .{ }^{11}$ In the Hong Kong population, however, the proportion of THR performed for rheumatoid arthritis increased between 1972-1997 and 19982010. We postulate that such discrepancy is due to our delay in adopting an early strict treatment strategy for rheumatoid arthritis. It has been shown by various studies that joint destruction occurs early in the course of rheumatoid arthritis. ${ }^{22-24}$ Early disease control is essential to prevent joint destruction and hence, need for joint replacement surgery. Such a concept had been incorporated in the European League Against Rheumatism treatment guideline of 2007. ${ }^{22}$ Despite this, it is only recently that the Hong Kong Society of Rheumatology has modified the local treatment guidelines on rheumatoid arthritis. ${ }^{25}$ Future epidemiological study might be needed to observe any changes in primary THR requirement for rheumatoid patients.

In this study, the disease leading to THR was entered by the operating surgeon based on clinical, radiological, and intra-operative assessments. Nonetheless, the underlying aetiology is sometimes difficult to determine in patients with end-stage arthritis and those with multiple risk factors. This causes possible information bias, and is a limitation of this study.

All data within the study period were pooled for analysis. Hence, any significant changes within the period from 1998 to 2010 might have been missed. In addition, data from this study were limited to a regional hospital in Hong Kong and generalisation of the results to the present Chinese population might not be accurate. A total of 15 hospitals were performing THR within the study period, and QMH accounted for $15 \%$ of surgeries. As a university teaching hospital, QMH also serves as a tertiary and quaternary referral centre in Hong Kong, and may therefore encounter a different disease spectrum compared with peripheral hospitals in Hong Kong. We believe a territory or nationwide joint registry, such as the Swedish Hip Arthroplasty Register or National Joint Registry (for England, Wales, Northern Ireland), is needed for more representative results. In view of the rising number of patients who suffer from advanced arthritis and hence, the rising number of joint replacement surgeries, the setting up of a joint registry is important for further research and budgeting of our health care resources.

\section{References}

1. Centers for Disease Control and Prevention (CDC). Prevalence of doctor-diagnosed arthritis-attributable activity limitation-United states, 2003-2005. MMWR Morb Mortal Wkly Rep 2006;55:1089-92.

2. Centers for Disease Control and Prevention (CDC). Prevalence of disabilities and associated health conditions among adults-United States, 1999. MMWR Morb Mortal Wkly Rep 2001;50:120-5.

3. Stoddard S, Jans L, Ripple J, Kraus L. Chartbook on work and disability in the United States, 1998: an InfoUse report. Washington DC: US National Institute on Disability and Rehabilitation Research; 1998.

4. Hootman JM, Helmick CG. Projections of US prevalence of arthritis and associated activity limitations. Arthritis Rheum 2006;54:226-9.

5. Murphy LB, Helmick CG, Schwartz TA, et al. One in four people may develop symptomatic hip osteoarthritis in his or her lifetime. Osteoarthritis Cartilage 2010;18:1372-9.

6. Ibrahim SA. Racial variations in the utilization of knee and hip joint replacement: an introduction and review of the most recent literature. Curr Orthop Pract 2010;21:12631.

7. Chang RW, Pellisier JM, Hazen GB. A cost-effectiveness analysis of total hip arthroplasty for osteoarthritis of the hip. JAMA 1996;275:858-65.

8. Emejuaiwe N, Jones AC, Ibrahim SA, Kwoh CK. Disparities in joint replacement utilization: a quality of care issue. Clin Exp Rheumatol 2007;25(6 Suppl 47):44-9.

9. Singh JA, Vessely MB, Harmsen WS, et al. A populationbased study of trends in the use of total hip and total knee arthroplasty, 1969-2008. Mayo Clinic Proc 2010;85:898904.

10. National Joint Registry for England, Wales and Northern Ireland 10th Annual Report; 2013.

11. The Swedish Hip Arthroplasty Register Annual Report 2011; 2012.

12. Lai YS, Wei HW, Cheng CK. Incidence of hip replacement among national health insurance enrollees in Taiwan. J Orthop Surg Res 2008;3:42.

13. Lau EM, Symmons DP, Croft P. The epidemiology of hip osteoarthritis and rheumatoid arthritis in the Orient. Clin Orthop Relat Res 1996;(323):81-90.

14. Chiu KY, Ng TP, Poon KC, Ho WY, Yau WP. Primary total hip replacement in Hong Kong Chinese-a review of 647 hips. Hong Kong J Orthop Surg 1998;2:114-9.

15. Singh G, Krishna L, Das De S. The ten-year pattern of hip diseases in Singapore. J Orthop Surg (Hong Kong) 2010;18:276-8. 
16. Harris WH. Traumatic arthritis of the hip after dislocation and acetabular fractures: treatment by mold arthroplasty. An end-result study using a new method of result evaluation. J Bone Joint Surg Am 1969;51:737-55.

17. Alcohol and health: Hong Kong situation. Hong Kong SAR: Department of Health. Available from: http://www.dh.gov. $\mathrm{hk} /$ english/pub_rec/pub_rec_ar/pdf/ncd_ap2/action plan_2_alcohol\%20and\%20health\%20HK\%20situation_e. pdf. Accessed Sep 2015.

18. Wang Y, Yin L, Li Y, Liu P, Cui Q. Preventive effects of puerarin on alcohol-induced osteonecrosis. Clin Orthop Related Res 2008;466:1059-67.

19. Cruess RL. Osteonecrosis of bone. Current concepts as to etiology and pathogenesis. Clin Orthop Related Res 1986;(208):30-9.

20. Jones JP Jr. Concepts of etiology and early pathogenesis of osteonecrosis. Instr Course Lect 1994;43:499-512.

21. Pachore JA, Vaidya SV, Thakkar CJ, Bhalodia HK,
Wakankar HM. ISHKS joint registry: A preliminary report. Indian J Ortho 2013;47:505-9.

22. Combe B, Landewe R, Lukas $C$, et al. EULAR recommendations for the management of early arthritis: report of a task force of the European Standing Committee for International Clinical Studies Including Therapeutics (ESCISIT). Ann Rheum Dis 2007;66:34-45.

23. Bakker MF, Jacobs JW, Verstappen SM, Bijlsma JW. Tight control in the treatment of rheumatoid arthritis: efficacy and feasibility. Ann Rheum Dis 2007;66 Suppl 3:iii56-60.

24. Grigor C, Capell H, Stirling A, et al. Effect of a treatment strategy of tight control for rheumatoid arthritis (the TICORA study): a single-blind randomised controlled trial. Lancet 2004;364:263-9.

25. Mok CC, Tam LS, Chan TH, Lee GK, Li EK; Hong Kong Society of Rheumatology. Management of Rheumatoid arthritis: consensus recommendations from the Hong Kong Society of Rheumatology. Clin Rheumatol 2011;30:303-12.

\section{Corrigenda}

"Childhood intussusception: 17-year experience at a tertiary referral centre in Hong Kong" (December 2015;21:51823). In this paper, the name of the fifth author was given incorrectly. The correct name should be "Wendy WM Lam" instead of “Wendy MW Lam”, and the corresponding Chinese name should be “林慧文” instead of “林文慧”. We regret the error. The article is correct at www.hkmj.org. 